\title{
Trade Politics and the Fast Track: \\ Impact on Congressional-Presidential Relations ${ }^{1}$
}

\author{
Byron W. Daynes, Brigham Young University \\ Glen Sussman, Old Dominion University
}

Congress and the President share responsibility for trade policy. While Congress has constitutional advantages in controlling trade, the President, through his powers to initiate and administer policy, can counteract these advantages and circumvent Congressional checks on presidential action. Methods for making trade policy-treaty making, executive agreement and fast tracking-bring the President and Congress into very different relationships. Fast tracking is an arrangement between Congress and the President that brings closure to multilateral and bilateral trade agreements without burdening the agreement with Congressional amendments. Under fast tracking, the President shapes trade policy from beginning to end; the Congress, which only has input through its elite trade committees, only can accept or reject such policy, without altering it. This makes fast tracking the latest and in some ways the most critical mechanism of presidential dominance in trade policy. Such a process has policy implications for members of Congress and threatens to change how Congresspersons govern and represent their constituencies. By altering the extent to which a member of Congress can shape trade policy, fast tracking potentially frustrates legislative representation, reduces Congress to a passive institution of response, and thus poses a major challenge to the traditional relationship between the President and Congress.

While the Congress and the President share responsibility for trade policy, it is the President who appears to have the advantage. The Constitution in Article I, Section 8, gives to the Congress powers to " . . lay and collect taxes, duties, imposts and excises . . .," as well as the power to "regulate commerce with foreign nations and among the several States ..." But it is the President's Article II powers as commander-in-chief, his treaty powers, his power to bind nations through executive agreement, his acknowledged leadership over foreign policy, his skills as legislative leader, and his advantages under fast tracking that provide him with real leverage over trade.

While the trade relationship between the President and Congress has changed over time and may well do so in the future, the advantages of the Executive appear clear. This pattern first became evident in the Reciprocal Trade Agreements Act of 1934, noted by some social scientists (e.g., Clausen 1973, 43; Nelson 1989, 89; Haggard 1988, 91-119; Hayes

BYRON W. DAYNeS is Professor of Political Science at Brigham Young University.

Glen Sussman is Assistant Professor of Political Science at Old Dominion University.

The American Review of Politics, Vol. 15, Spring, 1994: 73-87

๑ 1994 The American Review of Politics 
1981; and Bauer, Pool and Dexter 1963,11) as a landmark in altering the relations between these two institutions. This act ceded authority to the President to set tariff rates, an action that previously had been under Congress' jurisdiction. It was the Trade Act of 1974, however, that extended the President's authority well beyond the 1934 Act, allowing him not only to reduce tariffs, but to eliminate nontariff trade barriers through the process of fast tracking.

The purpose of this paper is to examine the fast tracking procedure as it affects both the President and Congress. While it is purported to be a way to bring the President and Congress into closer cooperation over trade policy, fast tracking instead alters the functional relationship between the two institutions, giving clear dominance to the Executive. The method of examining fast tracking will consist of probing the fast tracking procedure as well as analyzing the 1991 vote that gave Congresspersons for the first time an opportunity to formally express themselves on this procedure.

\section{The Fast Track}

\section{Background}

In 1973 President Richard Nixon asked Congress ". . . to delegate significant new negotiating authorities to the executive branch" (CQWR 14 April 1973, 852). This added authority was to allow the President to reduce tariffs and lower the nontariff barriers in order to enhance the bargaining position of the United States during the approaching General Agreement on Tariffs and Trade (GATT) negotiations that would involve 107 different countries (1973 CQ Almanac 1974, 42A-47A). Known today as fast tracking, the procedure devised in 1973 to allow the President to do this permits the President and the U.S. Trade Representative to negotiate an agreement with a country, write an implementing bill, and present it to the Congress. Under a legislative veto procedure, ${ }^{2}$ the House Ways and Means Committee and the Senate Finance Committee then have 45 legislative days in which to respond to the implementing bill. If a decision is not made within the time allotted, the measure automatically is discharged from the committees, and reported to the floor. The Committees and Congresspersons on the floor have a total of 90 days, from the time of the bill's first submission, in which to vote by majority to approve or disapprove the bill, but the decision must be made without modifications or change (Taylor 1993). In both chambers debate is limited to 20 hours (P.L. 93-618, section 151, 2001-2004).

The 1973 supporters and opponents of this request for added power immediately recognized what a change this would bring to the relationship 
between the President and Congress on trade matters. As Representative Wilbur Mills (D-AR), who then was chair of the House Ways and Means Committee, suggested of Nixon's request:

He is asking for more of a grant of authority than we have given any other President .... This is a touchy subject in Congress right now. But it is essential if we are to move forward. I'm for it (CQWR 14 April 1973. 848).

Congress agreed with Mills and conceded limited approval to the fast tracking procedure, feeling that the necessity of further consultation of the many countries involved in GATT would make it difficult to renegotiate any changes that Congress might propose. However, Congress did ask that during such negotiations the Administration consult with the House Ways and Means Committee and the Senate Finance Committee as well as their pertinent subcommittees handling trade matters in structuring the agreements.

Fast tracking was not to be a permanent authority of the President's, nor one that was to be applied generally to all trade matters, even though, as Senator Paul S. Sarbanes $(1992,53)$ charged, the Bush Administration tried to present fast tracking as a "standard operating procedure" that applied not only to the multilateral GATT trade negotiations but also to the bilateral NAFTA negotiations with Mexico. ${ }^{3}$

Nixon originally asked for fast tracking authority for five years. Since then, it has been renewed for shorter periods of time in the Trade Agreements Act of 1979, the Tariff and Trade Act of 1984, and the Omnibus Trade Competitiveness Act of 1988 (P.L. 96-39, P.L. 98-573, P.L. 100418) ${ }^{4}$ The only time that a President ever asked for permanent fast tracking authority (in 1988), Congress refused to grant it (1988 CQ Almanac 1989, 226).

Although fast tracking is not the most popular method of negotiating and legitimatizing trade agreements (treaty making and executive agreements being more frequently used), ${ }^{5}$ the increasing salience of fast tracking in contemporary Congressional debates encourages further analysis and examination of this trade instrument.

\section{The 1991 Fast Track Votes}

In the 1988 Omnibus Trade Competitiveness Act a provision was made for the President to request an extension of fast tracking that would continue this procedure through 1 June 1993, as long as neither house of Congress disapproved (P.L. 100-418, section 1103b[1][B]). President Bush made this request for an extension of the fast tracking procedure on 1 March 1991, but it also was accompanied by two disapproval resolutions submitted by the 
Congress-one by the House on 6 March 1991, and one by the Senate on 13 March 1991 (U.S. Congress-House 1991, 1; U.S. Congress-Senate $1991,1)$.

Thus, in 1991 members of Congress had the opportunity for the first time to vote on fast tracking as a process, separate from the trade issue (here, the North American Free Trade Agreement) it was part of. No longer was it an issue handled "quietly" behind the scenes by the Congressional trade committees and the U.S. Trade negotiator (Destler 1992, 208).

The three votes of 23 May 1991 examined here relate to the House's disapproval of fast tracking and illustrate the division between members of the House and Senate. The first vote involves a procedural matter to bring the resolution disapproving fast tracking before the House. This measure, H.R. 158, was adopted by a vote of 274-148 with Republicans supporting it 144-17, and Democrats opposing it 129-131, with one Independent vote in support. The second House vote concerns the disapproval resolution itself-H.R. 101-which would have dispensed with fast tracking for two years. It was rejected 192-231. Partisan differences were evident as Republicans supported the Administration's position by voting 21-140 to reject the disapproval, while Democrats voted 170-91 for disapproval (against the President's position). Once the crucial disapproval vote had been defeated, the final vote on adoption of the two-year extension (H.R. 146) showed greater support for the position held by both the President and the Democratic Congressional leadership. The vote for adoption was 329-85, with Republicans almost totally supportive (156-4), Democrats giving majority support (173-80), and the lone Independent voting against the measure (CQWR 25 May 1991, 1408).

The one Senate roll call vote dealing with the 1991 disapproval of the extension of fast tracking was the vote on S.R. 78. This measure was comparable to H.R. 101 mentioned above. The vote to adopt disapproval was 36-59, with Republicans voting overwhelmingly against disapproval (5-36), and Democrats supporting disapproval by a very close margin (31-23) (CQWR 1 June 1991, 1464).

The 1991 votes on the fast track also reflected the influence of geographic region (see Table 1). The trade debate over NAFTA during the early 1990s created unusual regional conflict. Cooper and Behr (1993, A1, A6) note that ". . . the NAFTA debate has marked the most significant return of regional politics on major legislation since the civil rights debates of the 1960s, which pitted the South against the rest of the country." Congresspersons who represented regions affected by high unemployment or states with special interests in need of protection tended to oppose fast 
tracking, seeing it as a process that reduced their role in policy making. As Senator Paul Sarbanes (D-MD), who saw fast tracking as threatening some of the interests he represented, put it: ". . . we are not sent here by our States and by the people we represent simply to abdicate that authority [the authority to render a judgment] to the executive, reserving only the ultimate authority of saying yes or no to a total package which contains within it innumerable tradeoffs and bargains, some of which may sacrifice very important regional and sectoral economic interests" (Sarbanes 1992, 55).

Congressional voting by region in 1991 indicated that of the nine regions of the United States, ${ }^{6}$ Senators and Congresspersons in the Mountain and West South Central states were most supportive of fast tracking, while Representatives and Senators in the East North Central, Middle Atlantic, New England, South Atlantic, and East South Central states-regions that have been troubled with high unemployment over the recession years (U.S. Department of Commerce 1990, 399)-were less supportive of fast tracking on these four 1991 roll call votes.

Table 2 examines the four fast track votes by individual chamber. Notwithstanding some variation, it appears that all four legislative votes on fast tracking in both chambers were influenced to some degree by their regional orientation.

\section{Table 1. Level of Congressional Support for 1991 Fast Tracking by Region}

\begin{tabular}{|c|c|c|c|c|}
\hline $\begin{array}{l}\text { Strong Suppor } \\
\text { for Fast Track }\end{array}$ & & $\begin{array}{l}\text { Moderate } \\
\ldots . . .\end{array}$ & & $\begin{array}{l}\text { Weak Support } \\
\text { for Fast Track }\end{array}$ \\
\hline - Mountain & - Pacific & $\begin{array}{l}\text { Middle } \\
\text { Atlantic }\end{array}$ & $\begin{array}{l}\text { South } \\
\text { Atlantic }\end{array}$ & $\begin{array}{l}\text { East } \\
\text { North } \\
\text { Central }\end{array}$ \\
\hline $\begin{array}{l}\text { West } \\
\text { South } \\
\text { Central }\end{array}$ & & $\begin{array}{l}\text { West } \\
\text { North } \\
\text { Central }\end{array}$ & $\begin{array}{l}\text {-New } \\
\text { England }\end{array}$ & $\begin{array}{l}\text { East } \\
\text { South } \\
\text { Central }\end{array}$ \\
\hline
\end{tabular}

NOTE: The nine regions classified in this Table are based on the U.S. Bureau of Census geographical divisions (see note 6). 


\section{Table 2. Differences in House/Senate Support for 1991 Fast Track Legislation by Region*}

H158

Support

Oppose

Vote on Measure

Vote on Measure

$\begin{array}{ccccccc}- \text {-Mt.** } & \text {-Mid.Atl. } & \text {-Pac. } & \text {-So.Atl. } & \text {-E.So.Cen. } & \text {-N.Eng. } & \text {-E.No.Cen. } \\ \text {-W.So.Cen. } & \text {-W.No.Cen. } & & & & \\ (83 \%) & (80 \%) & (69 \%) & (66 \%) & (65 \%) & (61 \%) & (51 \%)\end{array}$

\section{H101}

Support

Oppose

President (Fast Track)

President (Fast Track)

$\begin{array}{ccccccccc}\text {-W.So. } & \text {-Mt. } & \text {-Pac. } & \begin{array}{c}\text {-W.No. } \\ \text { Cen. }\end{array} & \begin{array}{c}\text {-E.So. } \\ \text { Cen. }\end{array} & \begin{array}{c}\text {-Mid. } \\ \text { Atl. }\end{array} & \begin{array}{c}\text {-So. } \\ \text { Atl. }\end{array} & \begin{array}{c}\text {-E.No. } \\ \text { Cen. }\end{array} & \text { Eng. } \\ (80 \%) & (75 \%) & (60 \%) & (55 \%) & (54 \%) & (49 \%) & (47 \%) & (46 \%) & (35 \%)\end{array}$

\section{H146}

Support

Oppose

Fast Track

-Mt.

$$
\begin{aligned}
& \text {-W.So. } \\
& \text { Cen. } \\
& (91 \%)
\end{aligned}
$$

-So. Atl.

-Pac.

-W.No.

-E.So.

-E.No.Cen.

(96\%)

(90\%)

-Mid. Atl.

Cen.

-N.Eng.

578

Support

Oppose

President (Fast Track)

President (Fast Track)

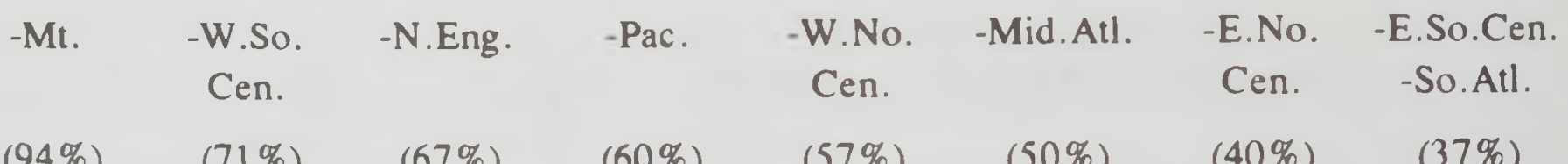
$(94 \%)$
(71\%)
(67\%) (60\%)
(57\%)
(50\%)
$(40 \%)$
(37\%)

* Percentage in parentheses represents the level of support for each measure determined by the vote by each state delegation aggregated by region.

**Abbreviations for the regions are as follows: Mt. = Mountain; Mid.Atl. = Middle Atlantic; W.So.Cen. = West South Central; W.No.Cen. = West North Central; E.So.Cen. = East South Central; E.No.Cen. = East North Central; Pac. = Pacific; N.Eng. = New England; So.Atl. = South Atlantic. 


\section{The Impact of Fast Tracking: Institutional Relations, Policy-Making, Representation and Governing}

\section{Institutional Relations: President and Congress}

Regardless of whether one supports or opposes the fast tracking process, most Congresspersons would agree that the President has been the major beneficiary of this trade policy mechanism. In 1973, while debating fast tracking, House Ways and Means Trade Subcommittee chair Charles A. Vanik (D-OH) charged that the President "seeks a transfer of unprecedented authority from the Capitol to the White House . . I I cannot give the White House authority to enter into secret and starchamber trade deals and then permit the dealers to shroud their action in executive privilege" (U.S. Congress-House 1973, 11781).

Supporters of fast tracking are not particularly concerned about this power shift and prefer to see the new relationship between Congress and President as an ideal partnership, or compact, that invites Congress to become involved in each stage of the trade negotiations through consultation with the President. To do anything other than to support fast tracking, in the words of then-Senator Lloyd Bentsen (D-TX), is to ". . . deny these negotiations dead in their tracks. It is inconceivable to me that the United States would deny itself the ability to negotiate away all the protectionism around the world that is facing us when our products are so ready to go to export to add jobs in this country. It would be a kind of unilateral disarmament on trade" (Bentsen 1992, 40). While Congress does have the right to modify the terms of the partnership if they are unfavorable, ${ }^{7}$ and can withdraw from an agreement arranged by the Executive, it is not clear that the Congress will do so once the negotiations have been concluded. Supporters point to October 1990, when the House of Representatives brought fast track procedures to a halt during consideration of most-favored-nation status for China. Nevertheless, opponents of fast tracking remain skeptical. ${ }^{8}$ The House Rules Committee that had supported fast tracking admitted that breaking a fast track agreement ". . . is not a step taken lightly and it requires a determined majority of the House united in its will to derail fast-track" (U.S. Congress-House 1991, 4). Moreover, former Representative Byron Dorgan (D-ND) indicates that one cannot always trust that the trade negotiators will live up to the bargains made with the Congress:

My experience with the 'trust us' plea of administration negotiators is that they'll promise the moon to get their agreement approved but promptly ignore those same promises after they've gotten what they want (Dorgan 1991. A11). ${ }^{9}$ 
Although it is not unusual for Congress to delegate authority to the President during trade negotiations, opponents of fast tracking see it as creating an imbalance of powers to the point where Congress' opportunity to shape trade policy is emasculated. As Representative Charles A. Vanik $(\mathrm{D}-\mathrm{OH})$ stated in 1974, when fast tracking was originally debated: "[t]he Congress should legislate trade policy-not abdicate responsibility. . . . This bill stakes out extensive authority for executive discretion-and this discretionary authority is carved out of the little that remains of the shattered and torn carcass of constitutional authority and responsibility" (U.S. CongressHouse 1991, H3504-H3505).

\section{Policy Types}

Has fast tracking changed the nature of trade policy as a result of the relationship it has established between the President and Congress? In his thorough examination of trade policy during the 1930s, E.E. Schattschneider (1935) observed the politics surrounding the passage of the Smoot-Hawley Tariff Act. He saw that tariff policy invited what Theodore J. Lowi later would call "distributive" politics. In Lowi's words, "His [Schattschneider's] political arena was decentralized and multi-centered, but relationships among participants were based upon 'mutual non-interference' among uncommon interests. The 'power structure' was stabilized toward the 'command posts' [in this case, the House Ways and Means Committee] . . ." (Lowi 1963, 680). Thus, as in all distributive policy, committees were the primary decisional actors, and in the tariff and trade area it was the House Ways and Means Committee and the Senate Finance Committee that were most important.

After 1954, decision-making on the tariff began to change. Lowi (1963, 701 ) observed that the House Ways and Means Committee began to weaken "as the tariff elite," and that in 1962 tariffs became regulatory (not distributive) policy, with the only vestiges of distributive politics remaining in "quotas and subsidies for producers of specific commodities injured by general tariff reductions" (Lowi 1963, 703)..$^{10}$

This overall change of the House Ways and Means Committee that Lowi identifies was followed by the important 1974 reforms that affected all House committees. I.M. Destler describes a series of changes that affected the House Ways and Means Committee, including an expansion in membership from 25 to 37 , opening mark-up sessions to the public, taking away the Committee's responsibility to act as the Democrats' Committee on Committees, and creating an important trade subcommittee that took some of the 
responsibility of trade from the chair of the full committee (Destler 1986, 59-60).

While these 1974 reforms weakened some of the strong House Committees, fast tracking-created in 1973 - strengthened the hands of the House Ways and Means Committee and the Senate Finance Committee, respectively. Under the fast track procedure, special trade authority and responsibilities were given to the House Ways and Means Committee; it became the House's primary access point, and principal consultation point, on trade matters. Moreover, under the skillful hands of Representative Dan Rostenkowski (D-IL), Ways and Means has exerted a major leadership role in supporting fast tracking. Similarly, the Senate Finance Committee in 1991 had a strong chair in Senator Lloyd Bentsen (D-TX). ${ }^{11}$ It was these two committees-not the membership of Congress-that largely influenced the scope, agenda, and course of the trade negotiations in the Congress. Both Rostenkowski and Bentsen aggressively encouraged a fast track victory for the President in 1991.

What is left to the discretion of the rank-and-file membership in Congress under fast tracking? Only a floor vote up or down, since the membership is unable to amend what the President negotiates in consultation with Ways and Means and Finance. Of course, individual members could voice their concerns through the committees, but this process does not allow ready access to information for the rank-and-file member. The individual members were so uninformed about trade negotiations in 1991, for example, that they had to request information from outside governmental agencies to find out about the potential impact of the on-going North American Free Trade Agreement negotiations. Indeed, a number of Congresspersons talked of establishing special "watchdog" groups to monitor the trade negotiations (Eisenstadt 1991, 19). This is not what Lowi describes as a regulatory arena, where committees are relatively unimportant and where major decisions are made in Congress as a whole. The politics of trade today has all the markings of distributive politics. Certainly, fast tracking creates a distributive arena where committees act as the important primary decisionmakers, with the floor of Congress being of little or no consequence. Fast track politics also bears striking resemblance to Ripley and Franklin's crisis policy model, wherein the Executive branch dominates the primary decisionmaking. Although the President is the primary actor in crisis policy, Ripley and Franklin $(1991,75,186)$ acknowledge that some senior committee leaders and party leaders are in position to become important advisers to the President. Here Ripley and Franklin could have been describing the chairs of the House Ways and Means Committee and the Senate Finance 
Committee, respectively, as well as those party leaders who led the way in supporting fast tracking.

\section{Legislative Representation}

Fast tracking also may have an effect on the way Congresspersons represent their constituents-particularly those in opposition to the fast track. As far as Congress' primary functions, Congressional scholars agree that two of the most important are representation and law making. Representation can be explored by examining Vogler's analysis of four types of representation $(1988,43-44,48,59-61,64-65)$. Formal Representation consists of the authority the representative has to act for and in behalf of the constituent. Descriptive Representation is concerned with how reflective Congress is of the social and economic characteristics of society. Symbolic Representation refers to how constituents see themselves being represented by the Congressperson. Substantive Representation considers the way a Congressperson chooses to represent his or her constituents. Vogler, like Davidson (1969) before him, identifies three ways a Congressperson may represent constituents: as a delegate, attempting to reflect the interests of the constituency, as a trustee, representing not what constituents think important but what he or she considers important, or as a politico, a role combining the previous two.

With the President so dominant over trade matters placed on the fast track, it is difficult for members of Congress to exercise formal representation by speaking for their constituents' interests on trade matters. As one House member . Bernard Sanders (I-VT), explained his concern about the fast tracking process: "The people of my State sent me to Congress to deliberate, to debate, to determine to my best ability what laws would best serve Americans, and democratic tradition demands no less. An up or down vote denies democracy" (U.S. Congress-House 1991, 6).

Fast tracking also may interfere with Congresspersons representing their constituencies symbolically or as delegates, since under fast tracking representatives are unable to directly modify acts of Congress to better reflect their interests. Unless one is a member of the House Ways and Means Committee or the Senate Finance Committee, a vote up or down is not going to be persuasive to the constituents. Appeals by legislators can be made, of course, to the International Trade Administration, the U.S. International Trade Commission, or recommendations can be sent along to the U.S. Trade Representative for response, but this is not always satisfactory since, as Senator Jesse Helms (R-NC) charged, quite often these trade negotiations involve more than just trade. It may become ". . . a complex foreign 
policy issue that goes beyond the expertise of our trade representatives and should be carefully reviewed by Congress" ( Helms 1992, 51). Thus, unable to modify policy directly, the act of exhibiting formal and substantive representation becomes more difficult for the representative.

\section{Governing and Law Making}

Because of the President's dominance in this area, fast tracking could well interfere with the Congress' other basic function of governing or law making. Fast tracking does not allow the Senate or the House to deliberate extensively in formulating trade policy since the Representatives and Senators must consider such policy under a time limit. As one critic, Senator Ernest Hollings (D-SC), suggested, the Senate runs the risk of changing under fast tracking from an institution of deliberation to a "fast track body" without the effective oversight it has exercised over the Executive branch in the past (U.S. Congress-Senate 1991, S6559). Nor is the House protected from such change under fast tracking in the eyes of some Congressional leaders. Representative David Bonior, House Majority Whip, for example, was particularly concerned about how fast tracking threatened to change the nature of the chamber. As he indicated:

\footnotetext{
I am very negative on the fast tracking process. I don't think my colleagues understand this; they have a sense of it, but they don't basically grasp how much it erodes the basic power of the institution. It is a tremendous vehicle for the Executive, and I have ... generally opposed it . . . As a process itself . . it eats away at what we do; it is just a usurpation of our ability . . . it takes away the ability of the House to independently change things (Bonior 1993).
}

\section{Conclusion}

Is fast tracking, then, a way to bring Congress and the President into closer cooperation over trade policy, or is it a way of altering the relationship between the institutions, and bargaining away their traditional roles? As we have argued, fast tracking is both. It is a bargain between institutions that does bring closure to multilateral and bilateral trade agreements. Often it closes these agreements in a cleaner and neater fashion than if a multilateral agreement is burdened with amendments by House and Senate deliberations. Furthermore, in this age of interdependent economies and world trade, Congress increasingly may have difficulty in using the other methods of initiating trade policy that it has used in the past. Fast tracking is one way to approach the trade situation today, but it carries a heavy cost. There may be other ways that are not as damaging to the basic operations of the 
Congress, that do not make this institution so subservient to the powers of the presidency. ${ }^{12}$ Fast tracking places the President and trade representative in a position to control the entire trade policy process. Congress loses control of policy making both in the initial stage, since it cannot help frame the question, and in the later stages of the trade process because time constraints are imposed within which the members of Congress must consider the trade policy. Fast tracking takes congressional input and control away from the rank-and-file congressperson and gives it to the elite trade committees (Ways and Means and Senate Finance), thus making it more difficult for the individual congressperson to represent specific constituent interests under the pressures of the President's stated national goals.

Although the 1991 votes on fast tracking represented what I.M. Destler $(1992,208)$ called the fifth vote of confidence granted by Congress since 1974, congressional resentment of fast tracking clearly was seen in those regions of the country where jobs were most threatened, particularly in the so-called "Rust Belt" region of the East North Central sector of the United States, the region troubled with aging industry and unemployment and where Democrats predominate. Those representatives most enthusiastic about fast tracking were in regions most supportive of the Bush Administration and the Republican agenda. Although some important House Democratic leaders supported fast tracking, support for it was primarily a conservative Republican position with some needed support from Southern Democrats.

Fast tracking comes at a very high cost, a cost that has been paid by the Congress since 1974. It will continue to be costly as long as Congress refuses to think of other options and continues to be willing to grant the short term approval it has given for this procedure since its inception.

\section{NOTES}

\footnotetext{
'We wish to give special thanks to Professors Earl Fry and Raymond Tatalovich, Loyola University of Chicago, for reading the manuscript and offering helpful suggestions.

${ }^{2}$ See Martin's (1992) fine treatment of legislative vetoes and trade policy.

${ }^{3}$ Fast tracking was the method used in negotiating the North American Free Trade Agreement (NAFTA). This five-volume trade agreement established the world's largest free trade zone, including Canada, the United States, and Mexico. Fast tracking assured the President's position of strength vis-à-vis the Congress, allowing him to exercise his skills as legislative leader-bolstered by an increase in Executive pork-barrel activity-to secure the votes needed for passage. The Administration won passage of the measure in the House by a margin of 234 to 200, and in the senate by a margin of 61 to 38 (Cooper 1993, A1; and Dewar 1994, A1). The Clinton victory was not inexpensive, of course, with NAFTA supporters spending more than their opponents by a 30-to-1 margin. Taking all of the side agreements necessary for passage into account. Charles Lewis estimated the total cost to be at least $\$ 300$ million (Lewis 1993, C2).
} 
${ }^{4}$ President Clinton, in a 9 April 1993 press release, announced his intention to request fast track authority from the Congress to conclude the Uruguay Round of the GATT multilateral trade negotiations. The draft of the bill that Clinton will submit to Congress will have this extension built into it. He then would have to notify Congress by 15 December 1993 of his intent to enter into the Uruguay Round before 15 April 1994 (White House, Office of the Press Secretary 9 April 1993). The request for fast track authority would affect only the GATT arrangements and would not affect future bilateral or multilateral trade negotiations. Neither would the request affect NAFTA, since NAFT A already had been signed before 31 May 1993, assuring that Clinton would have fast track authority for this trade agreement. Limiting his request to GATT negotiations could, as Cloud (1993, 1076) argues, prevent a confrontation with Congress on a broader request for authority affecting all future trade agreements.

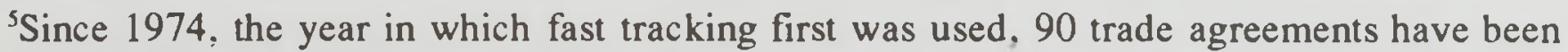
formalized, but only four of them were negotiated by fast tracking (U.S. Congress-House 1993, H3870).

${ }^{6}$ This analysis employs the U.S. Bureau of Census classification of regions in the United States. The distribution of states by region is as follows: New England (ME, NH, VT, MA RI, CT); Middle Atlantic (NY, NJ, PA); East North Central (OH, IN, IL, MI WI); West North Central (MN, IA, MO, ND, SD, NE, KS); South Atlantic (DE, MD, VA, WV, NC, SC, GA, FL); East South Central (KY, TN, AL. MS); West South Central (AR, LA, OK, TX); Mountain (MT, ID, WY, CO, NM, AZ, UT, NV); Pacific (WA, OR, CA, AK, HA).

${ }^{7}$ In at least one instance, Congress sent 50 of its members to accompany the trade negotiators to the Brussels GATT meetings (December 1990) to make sure that Congress would be fully informed and have some input in the initial negotiations.

${ }^{8}$ Representative Major Owens (D-NY), for example, does not think that fast tracking is that flexible. As he suggested: ". . . when the deal is made that the executive branch can go forward and negotiate a fast track agreement, nobody is going to break that deal. We have not had a leadership in the Democratic Party that breaks deals with the Administration" (U.S. Congress-House 1991, H3266).

${ }^{9}$ Representative Dorgan (1991, A11) indicated that promises had been broken three times during the negotiations surrounding the U.S.-Canadian Free Trade agreements. One of these found negotiators promising the Ways and Means Committee that U.S. wheat farmers would not be hurt by the agreement. As it turned out, however, the agreement allowed Canadian farmers to sell millions of bushels of durum wheat on U.S. markets while preventing U.S. farmers from selling any wheat to Canada, costing U.S. producers millions of dollars.

${ }^{10}$ Douglas Nelson saw the same trend, beginning with the Reciprocal Trade Agreement Act of 1934 , as the President took on additional authority to negotiate tariff reductions: "Economic interests were no longer able to lobby for an outcome with effective private effects. . . Instead they had to lobby over the general . . rules under which the administered protection mechanisms operated. That is, trade became what Lowi calls a regulatory issue" (Nelson 1989, 89-90).

${ }^{11}$ President Clinton's appointment of Lloyd Bentsen as his Secretary of the Treasury could be critical to the final passage of NAFTA. While Senator Bentsen's support was crucial in the early votes supporting NAFTA, it is unclear how supportive the new chair of the Senate Finance Committee, Senator Daniel Patrick Moynihan (D-NY), will be to its final passage. He has not been a strong advocate of this agreement in the past.

${ }^{12}$ Representative David Bonior (D-MI), House Majority Whip, suggests that if fast track remains an option to the Congress that Congress should think in terms of modification of the process. He suggests that fast track could be written so as to allow a certain type of amendment on a trade policy (Bonior 1993). Such modification would mollify some of the opposition to this procedure by those concerned about Congress' role. 


\section{REFERENCES}

Bauer, Raymond A., Ithiel de Sola Pool. Lewis A. Dexter. 1963. American Business and Public Policy: The Politics of Foreign Trade. New York: Atherton Press.

Bentsen, Lloyd. 1992. Should Congress Extend Fast Track Negotiating Authority? Congressional Digest (August: 40-46).

Bonior. David E. 1993. Interview by author. 15 December (tape recording). H107 Capitol Building. Washingion, DC

Clausen. Aage R. 1973. How Congressmen Decide: A Policy Focus. New York: St. Martin's Press.

Cloud. David S. 1993. Trade: Extension of Fast-Track Rules Seen Prodding GATT Talks. Congressional Quarterly Weekly Report I May: 1076.

1988 Congressional Quarterly Almanac. 1989. After Three Years. Trade Bill Finally Clears. 44: 226. Washington. DC: Congressional Quarterly Press.

1973 Congressional Quarlerly Almanac. 1974. Trade Reform: New Tariff Adjustment Powers Asked. 29: 42A-47A.

Congressional Quarterly Weekly Report 14 April 1973. Trade Reform Act: Nixon Asks Unprecedented Powers. $31: 848$.

14 April 1973. Text of Trade Message. 3i: 851-856.

25 May 1991. House Votes 114, 115. 116. 49: 1408-1409.

1 June 1991. Senate Votes 86. 49: 1464.

Cooper. Kenneth J. 1993. NAFTA Split Parties. Shuffled Politics as Administration Overtook Opponents. Washington Post 18 November: Al.

and Peter Behr. 1993. Sun Belt vs. Rust Belt: Trade Pact Debate Causes Regional Con-

flict. Washington Post 6 November: A1. A6.

Davidson. Roger W. 1969. The Role of the Congressman. New York: Pegasus.

Dewar, Helen. 21 November 1993. NAFT A Wins Final Congressional Test. Washington Post, Al.

Destler. I.M. 1986. American Trade Politics: System Under Stress. Washington, DC: Institute for International Economics.

1992. American Trade Politics, second ed. Washington, DC and New York: Institute for International Economics and The Twentieth Century Fund.

Dorgan, Byron L. 1991. Fast Track to Unfair Trade. Washinglon Post 20 May: Al1.

Eisenstadt. Todd. 1991. Keep the "Fast Track" Honest. Christian Science Monitor 21 August: 19.

Haggard. Stephen. 1988. The Institutional Foundations of Hegemony: Explaining the Trade Agreements Act of 1934. International Organization 42: 91-119.

Hayes, Michael T. 1981. Lobbyists and Legislators: A Theory of Political Markets. New Brunswick. NJ: Rutgers University Press.

Helms, Jesse. 1992. Should Congress Extend Fast Track Negotiating Authority? Congressional Digest (February: 41-51).

Journal of Commerce and Commercial. 27 February 1991: 8A. Approve Fast Track.

Lewis, Charles. 1993. The NAFTA-Math. Washington Post 26 December: C2.

Lowi, Theodore J. 1963 October/1964 July. American Business, Public Policy, Case-Studies, and Political Theory. World Politics 16: 677-715.

Martin, Elizabeth M. 1992. Fast Track and Free Trade: Why Does Congress Delegate? Paper presented at the annual meeting of the Midwest Political Science Association, Chicago, IL.

Nelson, Douglas. 1989. Domestic Political Preconditions of U.S. Trade Policy: Liberal Structure and Protectionist Dynamics. Joumal of Public Policy 9: 83-108.

P.L. 93-618. 1974. Trade Act of 1974.

P.L. 98-573. 1979. Trade Agreements Act of 1979.

P.L. 98-573. 1984. Tariff and Trade Act of 1984.

P.L. 100-418. 1988. Omnibus Trade Competitiveness Act of 1988. 
Ripley, Randall and Grace Franklin. 1991. Congress, the Bureaucracy, and Public Policy, fifth ed. Pacific Grove, CA: Brooks/Cole.

Sarbanes, Paul S. 1992. Should Congress Extend Fast Track Negotiating Authority? Congressional Digest (February: 53-55).

Schattschneider, E.E. 1935. Politics, Pressures and the Tariff: A Study of Free Private Enterprise in Pressure Politics, as Shown in the 1929-1930 Revision of the Tariff. New York: PrenticeHall.

Taylor. Andrew. 1993. Trade: Fast-Track Rules Get House OK. Congressional Quarterly Weekly Report 26 June: 1638.

U.S. Congress-House. 1993. Statement by Marcy Kaptur (D-OH), 103rd Cong., 1st Sess. Congressional Record 22 June: H3870.

1991. Committee on Banking, Finance and Urban Affairs. The U.S.-Mexican Free Trade Agreement: Hearing Before the Subcommittee on International Development, Finance, Trade and Monetary Policy of the Committee on Banking. Finance and Urban Affairs. 102nd Cong., 1st Sess., 16 April 1991: 6.

1991. Committee on Rules. Disapproving the Extension of Fast Track Procedures to Bills to Implement Trade Agreements Entered Into After May 31, 1991. Report 102-63, Part 1. 102nd Cong., 1 st Sess.: 1.

1991. Committee on Rules. Expressing the Sense of the House of Representatives With Respect to the United States Objectives that Should be Achieved in the Negotiation of Future Trade Agreements. Report 102-64. Part 1. 102nd Cong., 1st Sess., 15 May 1991: 4. 1991. North American Trade Agreement-Fast Track. 102nd Cong.. 1st Sess. Congressional Record 20 May 1991: H3266.

1991. An Address by Hon. John J. LaFalce Before the Council on the Americas.

102nd Cong., 1st Sess. Congressional Record 23 May 1991: H3504-H3506.

1973. Shall the President be a Trade Czar? 93rd Cong., 1st Sess. Congressional Record 11 April: 11781.

U.S. Congress-Senate. 1991. Committee on Finance. Disapproving the Request of the President for Extension of the Fast Track Procedures Under the Omnibus Trade and Competitiveness Act of 1988 and the Trade Act of 1974. Report 102-56. 102nd Cong., 1st Sess.: 1.

1991. Extension of Fast Track Procedures. 102nd Cong., 1st Sess. Congressional Record 16 April: S6559.

U.S. Department of Commerce. 1990. Statistical Abstract of the United States, 1990: The National Data Book. 110th ed. Washington, DC: Bureau of the Census.

Vogler, David. 1988. The Politics of Congress, fifth ed. Newton, MA: Allyn and Bacon.

The White House, Office of the Press Secretary. 9 April 1993. Statement by White House Press Secretary Dee Dee Myers on the Decision to Seek Fast Track Renewal. 